\title{
Dampak Intrusi Air Laut pada Kawasan Pesisir Surabaya Timur
}

\author{
Auke Herdyansah dan Dian Rahmawati \\ Departemen Perencanaan Wilayah dan Kota, Fakultas Teknik Sipil dan Perencanaan, Institut \\ Teknologi Sepuluh Nopember (ITS) \\ e-mail:dnrahmawati@gmail.com
}

\begin{abstract}
Abstrak-Intrusi air laut merupakan salah satu fenomena dimana air laut mencemari air tanah sehingga air tanah tidak dapat digunakan kembali oleh makhluk hidup diatasnya. Kota Surabaya merupakan salah satu dari sebagian kota besar yang memiliki kawasan pesisir. Berdasarkan data, kawasan pesisir timur di Kota Surabaya memiliki tingkat intrusi air laut yang cukup tinggi dengan nilai salinitas mencapai 47 ppt. Penelitian ini bertujuan untuk membuat rekomendasi pengembangan yang tepat berdasarkan fenomena intrusi air laut. Tahap awal dari penelitian ini adalah mengidentifikasi intrusi air laut pada wilayah studi. Tahap selanjutnya adalah mengeksplorasi dampak dari intrusi air laut dan bentuk tanggapan masyarakat terhadap dampak yang terjadi. Hasil dari kedua tahap tersebut kemudian di overlay menggunakan software $\operatorname{ArcGIS}$ untuk mengetahui besaran dampak yang terjadi sehingga dapat ditentukan bagaimana rekomendasi pengembangan yang tepat. Hasil penelitian menunjukkan bahwa wilayah yang memiliki tingkat intrusi air laut paling tinggi terdapat pada Kelurahan Gunung Anyar Tambak dan Kelurahan Medokan Ayu. Hasil temuan di lapangan juga menunjukkan bahwa dampak intrusi air laut yang paling dirasakan oleh masyarakat berhubungan dengan konstruksi bangunan dan konstruksi tanah. Hasil analisis juga menunjukkan pada wilayah studi bagian utara dan timur memiliki besaran dampak yang relatif besar, sehingga berdasarkan data tersebut dibuatlah beberapa rekomendasi pengembangan kawasan seperti regulasi terkait penggunaan lahan, edukasi kepada masyarakat, serta pemberlakuan program-program pemerintah dalam mengelola air tanah agar tidak semakin tercemari oleh air laut.
\end{abstract}

Kata Kunci-Intrusi Air Laut, Kawasan Pesisir Surabaya Timur.

\section{PENDAHULUAN}

$\mathrm{S}_{\mathrm{I}}^{\mathrm{U}}$ URABAYA merupakan salah satu kota pesisir di Indonesia yang memiliki garis pantai sepanjang 40,4 km. Kawasan pesisir Kota Surabaya meliputi 9 Kecamatan diantaranya, Benowo, Asemrowo, Krembangan, Pabean Cantikan, Kenjeran, Mulyorejo, Sukolillo, Rungkut dan Gunung Anyar. Sebagai salah satu kota metropolitan dan ibukota Provinsi Jawa Timur, intensitas penggunaan lahan pada kawasan pesisir dinilai cukup tinggi. Penggunaan lahan pada kawasan pesisir Kota Surabaya meliputi permukiman, budidaya tambak ikan maupun garam, militer, pergudangan, galangan kapal, pelabuhan dan tempat wisata [1].

Intensitas penggunaan lahan yang tinggi mengakibatkan kebutuhan air bersih yang juga tinggi, sehingga memungkinkan masyarakat untuk mengambil air tanah. Pengambilan air tanah secara berlebihan dapat menyebabkan perubahan arah aliran air tanah sehingga tekanan hidroststis akan mengalami penurunan dan terjadi intrusi air laut [2]. Intrusi air laut merupakan fenomena dimana air laut laut menembus lapisan akuifer air tanah (freshwater) sehingga kondisi air tanah menjadi asin seperti air laut.

Tingkat pencemaran air tanah karena intrusi air laut dapat diukur dengan melihat uji salinitas pada sampel-sampel air tanah. Pada kawasan pesisir Surabaya Timur, tercatat salah satu titik memiliki nilai salinitas mencapai 47 ppt [3]. Hal tersebut dapat diinterpretasikan bahwa telah terjadi intrusi air laut pada kawasan pesisir timur Kota Surabaya. Disamping hal tersebut, data pada Rencana Tata Ruang Wilayah Kota Surabaya memperlihatkan variasi penggunaan lahan pada kawasan pesisir timur Kota Surabaya seperti permukiman, tambak dan sawah yang diasumsikan akan terganggu oleh adanya fenomena intrusi air laut.

Intrusi air laut dapat mengakibatkan berbagai macam kerugian pada berbagai aspek kehidupan. Dampak dari terjadinya intrusi air laut antara lain (1) Penurunan muka air bawah tanah, (2) Keseimbangan hidrostatik akan terganggu, dan (3) Terjadi amblesan tanah karena pengambilan air tanah yang berlebihan. Sedangkan dapak terhadap penggunaan lahan diatasnya antara lain (1) Perumahan terdampak tidak akan memberikan fungsi yang optimal bagi penghuninya, (2) Tingkat kenyamanan pada hunian akan turun, dan (3) Kerugian bagi investor yang berinvestasi pada kawasan terdampak [4]. Salah satu kota di Indonesia yang mengalami intrusi air laut adalah Kota Jakarta. Salah satu dampak dari terjadinya intrusi air laut adalah kerugian yang dirasakan oleh petani di sekitar pesisir pantai Jakarta karena kebutuhan air tanah untuk irigasi berkurang. Selain tidak bisa digunakan untuk minum, air tanah di Jakarta juga tidak bisa digunakan untuk kegiatan MCK karena menyebabkan gatal-gatal pada kulit [5].

Dalam hal ini, Intrusi Air Laut dapat dikatakan sebagai tekanan yang dihadapi oleh sebuah kota pantai (urban coastal). Dalam prinsip Pengelolaan Wilayah Pesisir Terpadu, dijelaskan bahwan pembangunan dan pengelolaan kota pantai yang tidak melihat aspek lingkungan atau tidak mengimplementasikan integrasi antar sektor akan berdampak pada degradasi sumber daya pesisir, kualitas air di wilayah pesisir, penurunan peluang pembangunan infrastruktur serta ruang publik yang kehilangan fungsi utamanya [6]. Namun kecenderungannya banyak pemanfaatan dan pengelolaan sumber daya pada ruang pesisir yang berjalan dengan pola pembangunan yang tidak berkelanjutan. Konsep industrialisasi yang digagas bisa meningkatkan kesejahteraan masyarakat, terutama masyarakat di kawasan pesisir kian bergeser dengan 
banyaknya masyarakat miskin yang tinggal di kawasan pesisir [7].

Air tanah, khususnya pada kawasan pesisir, memiliki fungsi yang cukup vital bagi kehidupan manusia dan tumbuhan [8]. Intrusi Air Laut yang terjadi pada air tanah memiliki beberapa dampak yang dapat merugikan manusia baik secara langsung maupun dalam jangka panjang. Di sisi lain, intrusi air laut dapat semakin diperparah oleh kegiatan atau aktivitas manusia diatasnya yang memanfaatkan air laut secara berlebihan. Oleh karena itu diperlukan penelitian untuk mengetahui dampak dan besaran dampak intrusi air laut sehingga dapat menentukan rekomendasi pengembangan yang tepat untuk kawasan pesisir.

\section{METODE PENELITIAN}

\section{A. Jenis dan Pendekatan Penelitian}

Pendekatan penelitian yang digunakan dalam penelitian ini adalah pendekatan deduktif dan pendekatan eksploratif. Pendekatan deduktif merupakan penelitian yang mengharuskan peneliti memiliki background knowledge sebelum melakukan penelitian dan bertujuan untuk menguji sebuah teori atau hipotesis yang dikemukakan oleh peneliti [9]. Pendekatan penelitian eksploratif bertujuan untuk memberikan gambaran dasar mengenai topik bahasan serta membuka kemungkinan akan diadakannya penelitian lanjutan [10].

\section{B. Variabel Penelitian}

Variabel penelitian yang digunakan dalam penelitian ini diantaranya ekosistem buatan (penggunaan lahan), aktivitas masyarkat pesisir, tingkat salinitas, klasifikasi air tanah berdasarkan salinitas, konstruksi bangunan, nilai investasi bangunan, konstruksi tanah, kesuburan tanah, gangguan kesehatan, intervensi manusia, dan jangka waktu pemulihan. Seluruh variabel didasarkan pada tiga aspek utama penelitian ini, yaitu pengelolaan pesisir terpadu, intrusi air laut, dampak intrusi air laut dan penilaian dampak intrusi air laut.

\section{Mengidentifkasi Tingkat Intrusi Air Laut}

Identifikasi tingkat intrusi air menggunakan variabel tingkat salinitas dan klasifikasi air tanah berdasarkan salinitas. Pada tahap ini, diperlukan analisis interpolasi pada data salinitas dengan bantuan software ArcGIS 10.1. Interpolasi bertujuan untuk mengetahui prediksi suatu nilai pada setiap piksel raster berdasarkan data titik. Setelah dilakukan analisis interpolasi, hasil data kemudian disajikan berdasarkan klasifikasi air tanah berdasarkan salinitas.

Tabel 1.

Klasifikasi Air Tanah Berdasarkan Tingkat Salinitas

\begin{tabular}{cc}
\hline \hline Sebutan & Salinitas \\
\hline Air Tawar & \\
Fresh Water & $<0,5$ \\
Oligohaline & $0,5-3,0$ \\
Air Payau & $3,0-16,0$ \\
Mesohaline & $16,0-30,0$ \\
Polyhaline & $30,0-40,0$ \\
Air Asin & Marine \\
\hline \hline
\end{tabular}

Sumber : Mc Lucky dalam Purnomo (2013)

\section{Mengidentifkasi Dampak Intrusi Air Laut pada Wilayah Studi}

Identifikasi dampak intrusi air laut dilakukan dengan metode wawancara kepada responden yang telah ditentukan oleh kriteria responden. Kemudian, hasil wawancara dianalisis menggunakan metode content analysis dengan pembagian beberapa segment. Pembagian segment tersebut diantaranya konfirmasi kondisi air tanah, eksplorasi aktivitas masyarakat dan penggunaan air tanah, eksplorasi dampak intrusi air laut dan penilaian dampak berdasarkan variabel intervensi manusia dan jangka waktu penulihan.

Proses mengeksplorasi dampak melalui proses wawancara bertujuan untuk mengemukakan dampak intrusi air laut yang paling dirasakan oleh masyarakat. Luaran dari proses ini adalah jenis dampak yang dirasakan oleh masing-masing masyarakat yang telah ditentukan batas wilayahnya serta bentuk tanggapan masyarakat terhadap dampak yang dirasakan.

\section{E. Menganalisis Besaran Dampak Intrusi Air Laut}

Besaran dampak menjelaskan seberapa jauh dampak yang dirasakan oleh masyarakat terhadap tingkat intrusi air laut pada masing-masing wilayah. Variabel yang digunakan dalam proses ini adalah tingkat salinitas, intervensi manusia, dan jangka waktu pemulihan dampak. Metode analisis yang digunakan dalam proses ini adalah overlay menggunakan bantuan software ArcGIS 10.1. Luaran dari proses ini adalah besaran dampak dalam bentuk nilai yang disajikan dalam bentuk peta.

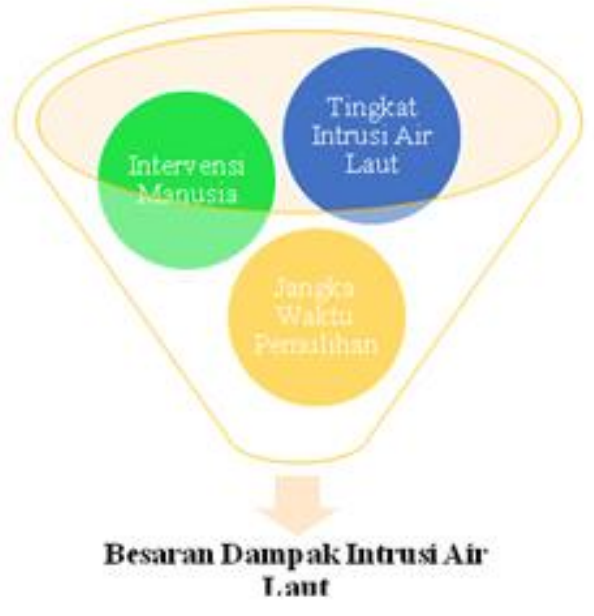

Gambar. 1. Ilustrasi analisis besaran dampak menggunakan variabel intervensi manusia, tingkat intrusi air laut dan jangka waktu pemulihan.

\section{F. Menentukan Rekomendasi Pengembangan Berdasarkan Fenomena Intrusi Air Laut.}

Penentuan rekomendasi pengembangan wilayah dilakukan dengan memperhatikan semua variabel yang digunakan dalam penelitian serta kajian literatur terkait permasalahan yang serupa. Metode analisis yang digunakan dalam penelitian ini adalah deskriptif kualitatif dengan pembagian berdasarkan besaran nilai dari besaran dampak yang telah dianalisis pada proses sebelumnya. 


\section{HASIL DAN PEMBAHASAN}

\section{A. Identifikasi Tingkat Intrusi Air Laut pada Wilayah Studi}

Wilayah studi yang digunakan dalam penelitian ini adalah Kecamatan Rungkut dan Kecamatan Gunung Anyar yang terletak di Kota Surabaya. Penentuan wilayah tersebut didasarkan pada hasil penelitian sebelumnya dan ketersediaan data uji salinitas yang telah dilakukan di Kota Surabaya. Berikut adalah hasil analisis interpolasi yang dilakukan berdasarkan uji salinitas pada sampel-sampel air tanah dan telah diklasifikasikan berdasarkan klasfikasi air tanah dari data salinitas.

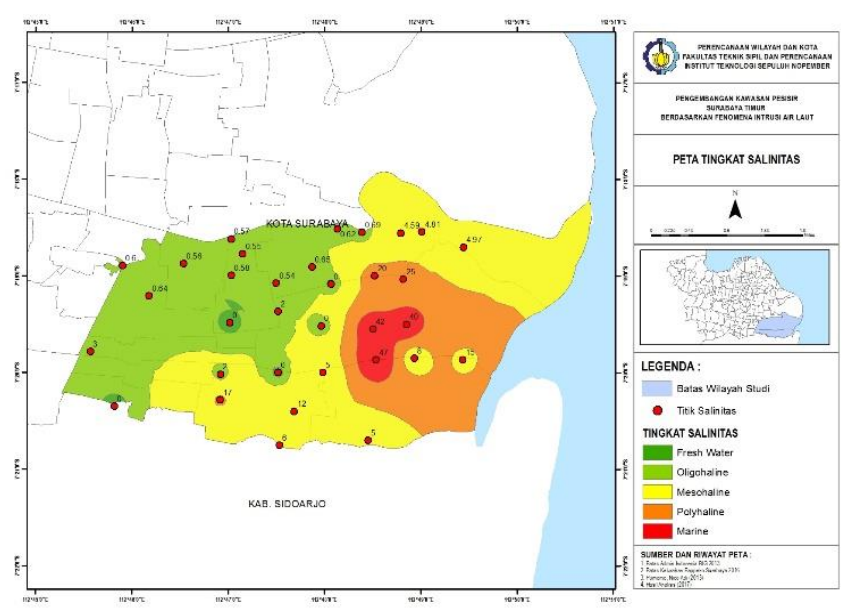

Gambar. 2. Hasil interpolasi data salinitas. Penyajian data telah disesuaikan dengan klasifikasi air tanah berdasarkan tingkat salinitas.

Berdasarkan hasil analisis, terlihat bahwa terdapat wilayah yang memiliki tingkat salinitas yang cukup tinggi. Untuk memfokuskan penelitian, maka dilakukan redeliniasi wilayah menjadi dua kelurahan yaitu Kelurahan Gunung Anyar Tambak dan Kelurahan Medokan Ayu. Berikut adalah peta tingkat salinitas dari kedua kelurahan tersebut.

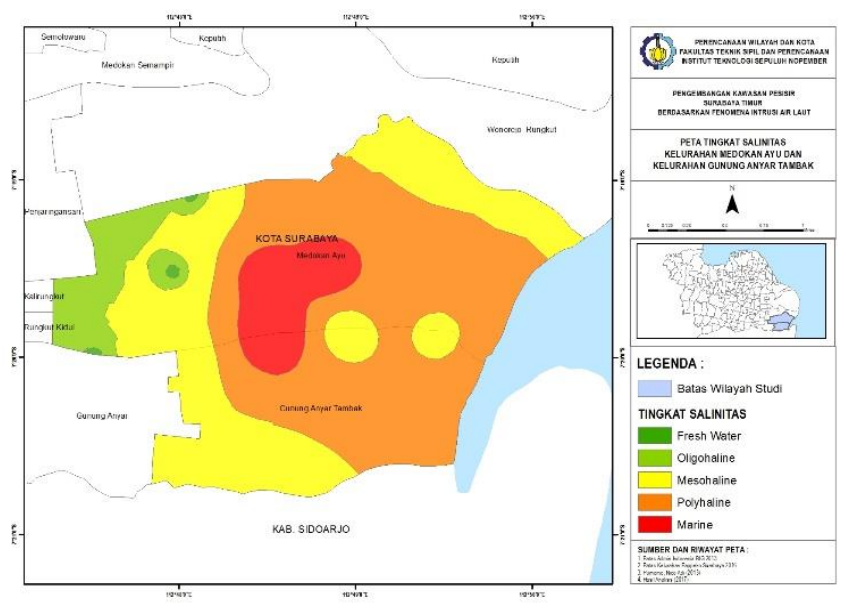

Gambar. 3. Wilayah studi yang digunakan berdasarkan hasil analisis.

\section{B. Mengidentifikasi Dampak Intrusi Air Laut}

Identifikasi dampak intrusi air laut dilakukan dengan metode wawancara pada 25 responden yang telah memenuhi kriteria. Pembagian responden tersebut didasarkan pada jumlah RW yang terletak di kedua kelurahan yang menjadi batas wilayah sehingga masing-masing responden mewakili setiap batas RW yang menjadi tempat tinggalnya.

Setelah melakukan wawancara, transkrip wawancara dianalisis menggunakan metode content analysis dengan pembagian empat segment. Berikut adalah contoh dari pembagian segment tersebut.

Pada segment 1, responden menyatakan bahwa kondisi air Tabel 1.

Contoh Kesimpulan Hasil Wawancara

\begin{tabular}{|c|c|c|}
\hline Segment & $\begin{array}{c}\text { Aspek } \\
\text { Pembahasan }\end{array}$ & Penjelasan \\
\hline Segment 1 & Kondisi air tanah & $\begin{array}{l}\text { Berbeda-beda, terdapat air tanah } \\
\text { dengan kondisi tawar dan asin. } \\
\text { Tidak terdapat air sumur. }\end{array}$ \\
\hline Segment 2 & $\begin{array}{l}\text { Aktivitas } \\
\text { masyarakat }\end{array}$ & $\begin{array}{l}\text { Mayoritas didominasi oleh rumah } \\
\text { tangga dan beberapa tambak di } \\
\text { bagian timur. }\end{array}$ \\
\hline Segment 3 & $\begin{array}{l}\text { Dampak intrusi air } \\
\text { laut }\end{array}$ & $\begin{array}{l}\text { Konstruksi bangunan berupa } \\
\text { keretakan dan cat tembok yang } \\
\text { mengelupas. } \\
\text { Perabotan yang terbuat dari besi } \\
\text { akan lebih cepat berkarat jika } \\
\text { diletakkan diluar ruangan. }\end{array}$ \\
\hline Segment 4 & Penilaian dampak & $\begin{array}{l}\text { Masih terdapat masyarakat yang } \\
\text { membutuhkan bantuan pihak lain } \\
\text { karena tidak mampu untuk } \\
\text { memulihkan kondisi dari dampak } \\
\text { intrusi air laut. } \\
\text { Jangka waktu yang diperlukan bisa } \\
\text { berlangsung lama karena menunggu } \\
\text { bantuan dari pihak luar. }\end{array}$ \\
\hline
\end{tabular}

tanah pada wilayah yang bersangkutan relatif berbeda-beda dan sudah tidak terdapat air sumur untuk kebutuhan seharihari. Pada segment 2, responden menyatakan bahwa aktivitas masyarakat didominasi oleh rumah tangga (permukiman) dan aktivitas tambak. Dampak intrusi air laut dijelaskan oleh responden pada segment 3, diantaranya konstruksi bangunan berupa cat yang sering mengelupas dan keretakan dinding rumah serta perabotan yang terbuat dari besi akan lebih cepat berkarat jika diletakkan di luar ruangan. Pada segment terakhir, responden menjelaskan masih terdapat masyarakat yang membutuhkan bantuan dari pihak lain untuk menanggulangi permasalahan yang ada (variabel intervensi manusia) dan jangka waktu yang diperlukan berlangsung lama karena harus menunggu bantuan dari pihak lain (variabel jangka waktu pemulihan).

Kesimpulan yang didapatkan dari proses ini adalah dampak utama yang sering muncul pada wilayah studi terkait dengan konstruksi bangunan dengan 18 kali muncul pada wilayah yang berbeda-beda dan kesuburan tanah dengan 8 kali muncul pada wilayah yang berbeda-beda.

\section{Menganalisis Besaran Dampak Intrusi Air Laut pada Wilayah Studi.}

Besaran dampak dihasilkan dari hasil analisis overlay data tingkat salinitas, nilai intervensi manusia dan jangka waktu pemulihan. Data tingkat salinitas didapatkan dari hasil analisis pada proses pertama, sedangkan nilai intervensi manusia dan nilai jangka waktu pemulihan didapatkan berdasarkan hasil wawancara proses sebelumnya pada segment 4 . Berikut adalah hasil analisis overlay yang disajikan dalam bentuk peta. 


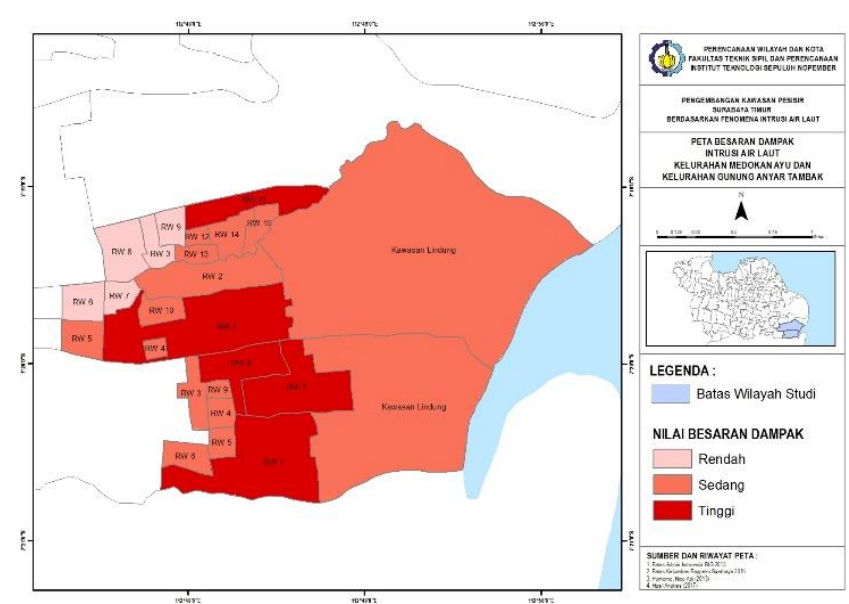

Gambar. 4. Hasil besaran dampak pada wilayah studi. Warna merah yang semakin gelap menunjukkan besaran dampak yang semakin tinggi.

1. Besaran dampak rendah : Besaran dampak rendah merupakan sebuah kondisi dimana suatu wilayah memiliki tingkat salinitas yang rendah dan penilaian terhadap dampak juga relatif rendah. Hasil analisis menyajikan data bahwa wilayah yang memiliki besaran dampak rendah berada pada Kecamatan Medokan Ayu di RW 03, RW 06, RW 07, RW 08, dan RW 09.

2. Besaran dampak sedang : Besaran dampak sedang merupakan sebuah kondisi dimana suatu wilayah memiliki tingkat salinitas dari rendah serta didominasi oleh sedang dan tinggi. Selain itu, penilaian masyarakat terhadap dampak relatif rendah dan sedang. Hasil analisis menyajikan bahwa besaran dampak sedang mendominasi wilayah studi baik pada Kelurahan Medokan Ayu maupun Kelurahan Gunung Anyar Tambak termasuk pada kawasan lindung yang berbatasan langsung dengan laut. Terdapat beberapa RW yang masuk dalam kategori sedang diantaranya RW 03, RW 04, RW 05, RW 06 dan RW 09 pada Kelurahan Gunung Anyar Tambak serta RW 02, RW 04, RW 05, RW 10, RW 12, RW 13, RW 14, dan RW 15 pada Kelurahan Medokan Ayu.

3. Besaran dampak tinggi : Besaran dampak tinggi merupakan sebuah kondisi dimana suatu wilayah memiliki tingkat salinitas dari sedang ke tinggi dan penilaian terhadap dampak intrusi air laut dari sedang ke sangat tinggi. Hasil analisis menyajikan data bahwa kondisi ini terjadi pada RW 01, RW 07 dan RW 08 pada Kelurahan Gunung Anyar Tambak serta RW 01 dan RW 11 pada Kelurahan Medokan Ayu.

\section{Menentukan Rekomendasi Pengembangan Berdasarkan Fenomena Intrusi Air Laut.}

Secara umum, pengembangan sebuah wilayah khususnya wilayah pesisir harus didasarkan pada prinsip pembangunan berkelanjutan sesuai dengan konsep Integrated Coastal Management (ICM). Manusia sebagai penyebab utama dalam sebagian besar kasus masalah lingkungan terutama pada kawasan pesisir, tidak dibenarkan untuk tidak mengizinkan manusia untuk tinggal di kawasan pesisir [11]. Pengembangan kawasan pesisir yang memiliki konsep pembangunan berkelanjutan harus memiliki prinsip bahwa sumberdaya yang ada harus dikelola dengan baik agar dapat dimanfaatkan untuk generasi selanjutnya.

Secara spesifik, rekomendasi pengembangan dibuat berdasarkan karakteristik masing-masing wilayah berupa nilai besaran dampak yang telah dianalisis pada proses sebelumnya. Berikut adalah rekomendasi pengembangan yang diberikan pada wilayah studi :

1. Besaran dampak rendah : Menurut laporan yang diterbitkan oleh Atlantic Climate Adaptation Solution Association : Saltwater Intrusion and Climate Change, hal tersebut dapat diminimalisir dengan regulasi yang mengatur penggunaan lahan dan pengembangan terutama pada kawasan pesisir [1]. Hal ini berkaitan dengan jenis aktivitas pada penggunaan lahan tertentu yang berpotensi terdapat eksploitasi sumberdaya air tanah. Disamping hal tersebut, Edukasi kepada masyarakat terkait intrusi air laut dari sisi penyebab, dampak serta upaya penanggulangan. Edukasi merupakan hal yang penting karena dengan edukasi kepada masyarakat, upaya penanggulangan intrusi air laut secara bottom up dengan melibatkan tokoh masyarakat akan lebih efektif jika dibandingkan dengan upaya top down dari pemerintah [7]. Edukasi pada kawasan dengan jenis besaran dampak rendah lebih kepada pengenalan intrusi air laut secara umum.

2. Besaran dampak sedang : Regulasi pengaturan penggunaan lahan juga perlu dilakukan pada wilayah ini, khususnya pada kawasan lindung yang menjadi barrier utama. Salah satu upaya untuk menanggulangi intrusi air laut adalah dengan membangun barrier seperti penanaman mangrove pada kawasan lindung. Tanaman mangrove memiliki fungsi sebagai penahan intrusi air laut karena akar-akar mangrove dapat mengendapkan lumpur yang telah bercampur dengan air asin. Hal tersebut tentu dapat mengurangi intensitas intrusi air laut yang menyebar sampai ke daratan.

3. Besaran dampak tinggi : Regulasi pengaturan penggunaan lahan pada wilayah dengan besaran dampak tinggi dapat dilakukan dengan pembatasan peruntukan untuk lahan terbangun. Hal tersebut dikarenakan mayoritas masyarakat pada wilayah ini merasakan dampak intrusi air laut jauh lebih signifikan jika dibandingkan dengan wilayah lainnya. Hal tersebut berpotensi jika terdapat lahan terbangun yang baru pada wilayah ini akan menimbulkan dampak yang relatif sama bahkan akan menambah jumlah masyarakat yang merasakan dampak dari intrusi air laut. Disamping hal tersebut, Program-program sosial dari pemerintah khususnya pada aspek kebutuhan tempat tinggal manusia perlu diperbanyak. Hal ini dikarenakan ada sebagian masyarakat yang masih belum mampu untuk memulihkan dampak dari intrusi air laur terutama pada aspek konstruksi bangunan. Bantuan-bantuan seperti program "bedah rumah" sangat dibutuhkan oleh masyarakat terutama masyarakat kurang mampu yang merasakan dampak dari intrusi air laut. Program tersebut dapat disesuaikan dengan bahan bangunan yang lebih tahan air asin atau dapat memminimalisir dampak yang merugikan masyarakat. Selain itu program pembangunan 
fasilitas umum seperti sumur resapan juga dibutuhkan sebagai upaya antisipasi jika penyedia sumber air bersih tidak berjalan dengan optimal agar masyarakat dapat menggunakan air tanah yang layak pakai sebagai alternatif [2].

\section{KESIMPULAN/RINGKASAN}

Kesimpulan yang dihasilkan dari penelitian ini adalah sebagai berikut :

1. Berdasarkan hasil analisis, ditemukan bahwa kecenderungan wilayah yang memiliki tingkat salinitas tinggi atau tingkat intrusi air laut yang tinggi adalah wilayah yang terletak pada bagian timur atau mendekati laut. Tingkat salinitas tertinggi pada wilayah studi terletak pada Kelurahan Medokan Ayu dan Kelurahan Gunung Anyar Tambak, sehingga dilakukan redeliniasi wilayah untuk lebih memfokuskan penelitian ini.

2. Dalam mengidentifikasi tingkat intrusi air laut, semua variabel yang dikemukakan dari hasil kajian pustaka terjadi pada wilayah studi. Berdasarkan kondisi di lapangan dan hasil analisis, ditemukan dampak-dampak lain yang disebabkan oleh intrusi air laut. Dampak yang paling umum dirasakan oleh masyarakat adalah terkait konstruksi bangunan dan kesuburan tanah.

3. Dalam menghitung besaran dampak intrusi air laut, ditemukan bahwa besaran dampak dengan tingkat sedang paling banyak terjadi pada wilayah studi. Secara umum masyarakat sudah sadar akan adanya intrusi air laut dan dampak yang ditimbulkan serta sudah bisa beradaptasi dengan kondisi yang ada. Namun, masih terdapat masyarakat yang belum mengerti dan belum bisa beradaptasi dengan dampak intrusi air laut.

4. Rekomendasi yang diberikan dalam tahapan terakhir berupa kegiatan pengelolaan yang bisa dilakukan untuk meminimalisir dampak intrusi air laut. Rekomendasi diberikan sesuai dengan kondisi yang ada pada masingmasing wilayah.

\section{DAFTAR PUSTAKA}

[1] ACASA, Saltwater Intrusion and Climate Change. Canada, 2011.

[2] Aulia, "Penurunan Permukaan Tanah: Penyebab, Dampak dan Upaya Penanggulangan," 2016. [Online]. Available: http://ilmugeografi.com/bencana-alam/penurunan-permukaan-tanah

[3] J. Dahuri, R., \& Rais, Pengelolaan Sumber Daya Wilayah Pesisir dan Lautan Secara Terpadu. Jakarta: PT Pradnya Paramita, 2001.

[4] D. K. dan P. P. J. Timur, Rencana Zonasi Wilayah Pesisir dan Pulau-Pulau Kecil Kota Surabaya. Surabaya, 2012.

[5] H. Efendi, Telaah Kualitas Air: Bagi Pengelolaan Sumber Daya dan Lingkungan Perairan. Yogyakarta: Kanisius, 2003.

[6] R. N. Indriastoni, "Intrusi Air Laut Terhadap Kualitas Air Tanah Dangkal di Kota Surabaya," Rekayasa Tek. Sipil, vol. 3, pp. 228232, 2014.

[7] Khumaedi, "Edukasi Fenomena Amblesan-Intrusi Air Laut dan Penanggulangannya di Semarang Utara," Abdimas, vol. 20, pp. 5560, 2016

[8] I. B. Mantra, Filsafat Penelitian dan Metode Penelitian Sosial. Yogyakarta: Pustaka Pelajar, 2004.

[9] S. Notodarmojo, Pencemaran Tanah dan AIr Tanah. Bandung: Penerbit ITB, 2005.

[10] D. Papatheochari, "Coastal Cities," 2007.

[11] D. Pamungkas, A., \& Rahmawati, Diktat Teori Perencanaan Kawasan Pesisir. Surabaya, 2014. 